\title{
What are the main concerns of human resource managers in organizations?
}

\author{
Amable Juarez-Tarraga ${ }^{1}(\mathbb{D})$, Cristina Santandreu-Mascarell ${ }^{1}(\mathbb{D})$ \\ Juan A. Marin-Garcia ${ }^{2}$ (D) \\ ${ }^{1}$ Departamento de Organización de Empresas. Universitat Politècnica de València (Spain) \\ ${ }^{2}$ ROGLE. Departamento de Organización de Empresas. Universitat Politècnica de València (Spain) \\ amjua@omp.upv.es,crisanma@omp.upv.es,jamarin@omp.upv.es
}

Received June, 2018

Accepted April, 2019

\begin{abstract}
Purpose: This study examines whether high involvement work programs (HIWP) are included in, and respond to, the priorities of HR managers in organizations. We analyze reports to identify the main concerns for managers, and compare the solutions implemented to address them, to evaluate the extent to which HIWP are adopted to meet these challenges.
\end{abstract}

Design/methodology: To conduct this study we carried out a systematic literature review, selecting reports by consulting firms and human resource management associations.

Findings: Our key findings from this research suggest that HIWP are used as a lever for change to meet the challenges faced by HR managers in organizations, the most urgent of which are talent management and improving leadership.

Research limitations/implications: The paper identifies possible lines of research that respond specifically to the interests of the professional ambit and would be better appreciated by HR managers in companies.

Practical implications: The issues raised are relevant to HR professionals, allowing them to compare their priorities against those of managers occupying similar positions, and to view a selection of the most commonly used programs to solve priority problems. This enables HRMs to plan ahead and prepare by providing them with an overview of the most important challenges they have to face.

Originality/value: On the one hand in the professional arena, as they provide professionals with an overview of the challenges they face, so they can plan optimal HR management programs, work methods geared and identify improvement opportunities. And on the other hand, in the academic sphere, our study opens possible future research lines that may contribute to the development of the profession, identify research lines that genuinely address the concerns of professionals and could help reduce the gap that some researchers have identified between the academic and professional spheres.

Keywords: Human Resource Management, Systematic literature review, practitioner needs, High Involvement Work Programs, Challenges, Concerns

Jel Codes: M120, M540 


\section{To cite this article:}

Juarez-Tarraga, A., Santandreu-Mascarell, C., \& Marin-Garcia, J.A. (2019). What are the main concerns of human resource managers in organizations?. Intangible Capital, 15(1), 72-95. https://doi.org/10.3926/ic.1342

\section{Introduction}

Globalization, technological advances, together with the economic recession affecting virtually all sectors to varying degrees, are all producing significant changes in the business environment (Stone \& Deadrick, 2015). To these external changes we must add internal factors, such as the impact of the increasing proportion of the workforce occupied by Millennials, who bring different values and behaviors to labor relations and a holistic view of the principal objectives of organizations (Deloitte, 2015).

All these changes place new demands on organizations and generate new ways of working, requiring professionals and managers to adapt at a rapid pace to ensure the survival of the company. Focusing on the area of human resources (HR), these changes can lead to restrictions on businesses such as fewer resources to undertake new projects, tighter training budgets and increasing job insecurity (Stone \& Deadrick, 2015). At the same time, however, HR departments are becoming increasingly important, being responsible for aligning the performance of each employee with the company mission and objectives. The HR function is changing focus from administrative efficiency towards creating value for clients, investors and society in general (Ulrich \& Dulebohn, 2015).

Against this background, this paper aims to identify the challenges facing HR professionals, and the solutions they put in place to address them. We conducted a literature review to answer the following research questions:

- What are the main concerns of human resource managers:

- The principal challenges they have to face, taking into account the internal and external factors that impact on them.

- What solutions they adopt to meet these challenges:

- Which programs are most commonly implemented in people management, and do these programs correspond to those traditionally identified as High Involvement Work Programs (HIWP).

- To what extent do implemented programs meet the challenges identified.

We feel that the issues raised are relevant to HR professionals, allowing them to compare their priorities against those of managers occupying similar positions, and to view a selection of the most commonly used programs to solve priority problems. This enables HRMs to plan ahead and prepare by providing them with an overview of the most important challenges they have to face. The questions are also relevant for academics, as they also identify possible lines of research that respond specifically to the interests of the professional ambit and would be better appreciated by HR managers in companies.

\section{Challenges for $H R$ practitioners}

Although organizations in general, and more specifically the HR function, are constantly subject to challenges, they are nonetheless more common in certain circumstances and periods of time. The panorama of changes occurring in the corporate environment over recent years and the societal transformations taking place in all areas with implications for the population in general, generate important new challenges for professions, not just on a short-term, specific and time-limited basis, but also on a more abstract, medium/long term level.

Although in some contexts the term "challenge" can be synonymous with "problem" or "threat", we approach the analysis from a positive viewpoint, which describes this term as "a difficult goal or task to perform, which thereby constitutes a stimulus for anyone addressing it" and the verb to challenge: "to brave difficulties decisively". From this 
perspective, defining the challenges faced by a particular group, in our case, HR professionals, and knowing when they are likely to emerge, helps HR managers to evolve and improve in management by enabling them to plan ahead, develop the best working tools and methods for success, and identify improvement opportunities.

In analyzing these challenges, we chose to make an in-depth evaluation of whether High Involvement Work Programs (HIWPs) as a whole play an important role. HIWP are a group of programs that act synergistically and improve organizational efficiency by creating job conditions that increase employee satisfaction, encouraging them to engage with the organization and perform better (Huselid, 1995). For our research purposes we adopted the integrated meaning of "program" as a set of formalized HR activities used in an organization, which must be distinguished from practices or climate, although they are closely related concepts (Arthur \& Boyles, 2007).

Traditionally, high performance programs contain varying "bundles" or constructs (Marin-Garcia \& Conci, 2013), but the lack of consensus among researchers on the structure of these programs (Marin-Garcia, 2013) has meant that researchers develop ad-hoc models in practically all new research.

Among the most influential HIWP models include Lawler's (1986), which includes the Training, Communication, Empowerment and Remuneration constructs; and the AMO model that includes Ability, Motivation and Opportunity constructs (see Figure 1). This latter model, originally proposed by Bailey (1993) as a strategic human resource management model, asserts that "employees perform well when they have the ability (they possess the necessary skills and knowledge), the motivation (because they are properly incentivized), and their work environment provides the necessary support and means (opportunity)".

These two models have conceptually different origins (Lawler centered on programs, and AMO focused on HR management), but bear many similarities within the scope of our study, since the AMO model integrates Lawler's model, albeit with a different structure (Marin-Garcia \& Martinez Tomas, 2016):

- The AMO construct "ability" includes encompasses the "training" construct of Lawler's model,

- The "motivation"construct contemplates Lawler's "remuneration", and finally

- The "opportunity" construct encapsulates in synthesis Lawler's "communication" and "empowerment" constructs.

A noteworthy feature of the model developed by Lawler is that it includes an official questionnaire to evaluate the use of high involvement programs, which has been used by various researchers (Marin-Garcia \& Conci, 2013), and despite the AMO model has also a questionnaire (Appelbaum, Bailey, Berg, Kalleberg, \& Cornell, 2000) its conceptual model has been used more than the questionnaire to take data. In this sense the AMO model was used as a conceptual framework for two important meta-analyses on the use of high performance programs (HIWP) (Jiang, Lepak, Hu, \& Baer, 2012; Subramony, 2009), that supported the link between these programs and corporate performance. It is also being used in multiple research programs to analyze human resource management (Boxall, 2012; Knies \& Leisink, 2014), explaining our choice of the latter model as the framework for our research.

Within each construct the AMO model includes a series of programs that are generally known as high performance work programs. The 13 programs included in the AMO model coincide largely with the 13 programs identified in the meta-analysis conducted by (Combs, Liu, Hall \& Ketchen, 2006). This work identified the high-performance programs that appeared most frequently in 92 previous studies: incentives, training, compensation, participation, selection, internal promotion, planning, flexible work hours, performance appraisal, grievance procedures, work teams, information sharing and job security. 


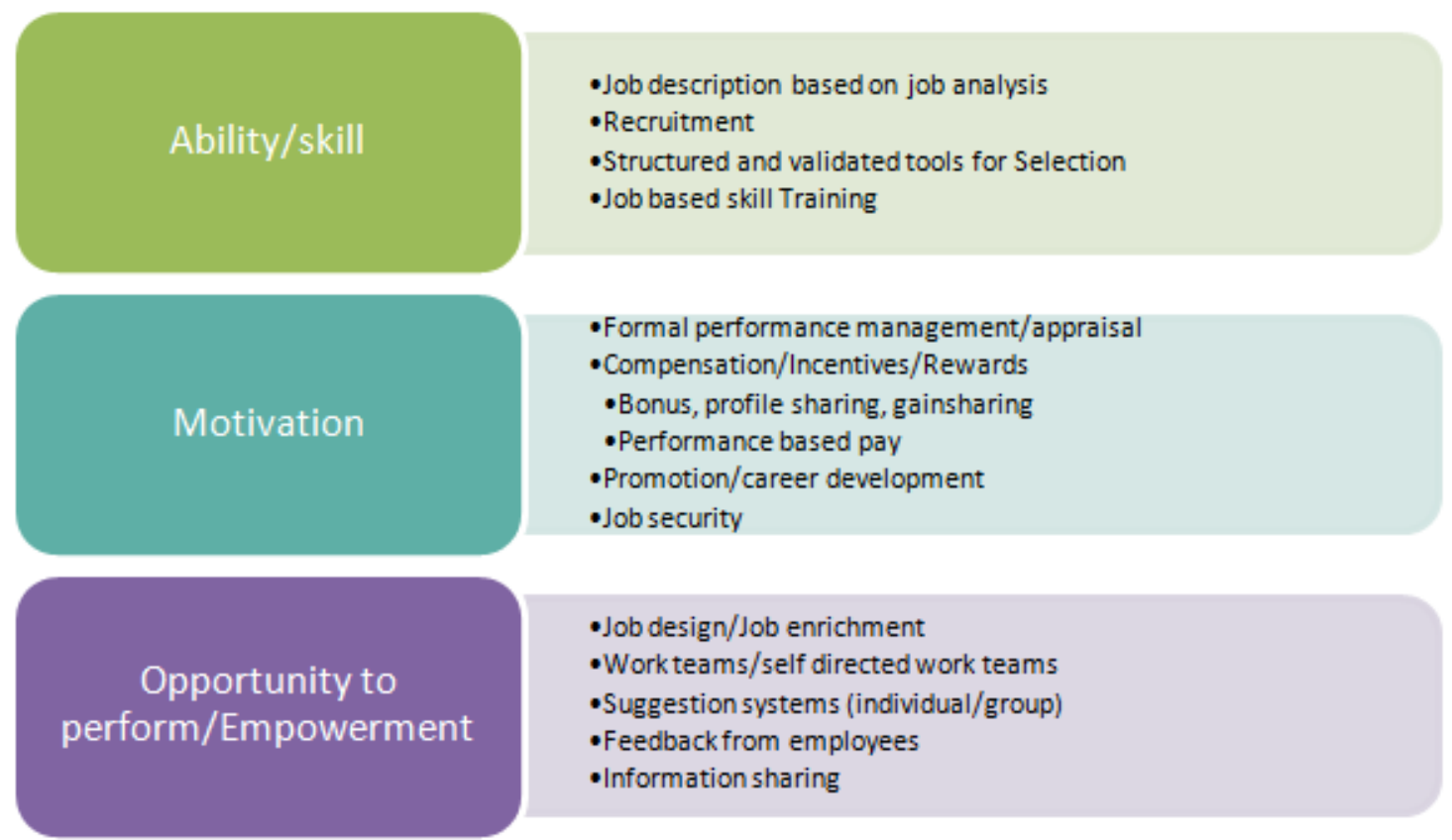

Figure 1. HIWP program design according to AMO model (Marin-Garcia, 2013)

Subsequent literature reviews (Perello-Marin \& Ribes-Giner, 2014) extend this list of programs to 42, grouped in eight categories: Recruitment and selection; Training and development; Appraisal and feedback; Compensation; Job design and job analysis; Internal communication and knowledge management (Information sharing); Employment security and commitment; and finally, Quality, active participation and teamwork. As can be seen, the categories in this study are also represented in the AMO model.

\section{Methodology}

Our approach to identify the challenges that HR professionals face and the solutions adopted to address them was to conduct a search of the peer reviewed literature until 2018, applying the following strategy [title: (challenge or matter or concern or perception or worry*) AND title: (human resource) Refined by: Research areas/domains/Subject: (Business or Economics or Psychology or Social Sciences)]. This search produced 186 results in WOS and 182 in Scopus. After reviewing the titles and abstracts 28 items were selected, but after analyzing the abstracts, only nine articles were found to address this issue, albeit tangentially. Finally, only one of them was used in our analysis, as the rest of the items assess isolated cases or provide a theoretical overview of the subject. This paucity of results in the search conducted on an academic level is in line with observations by Marin-Garcia (2013).

Our failure to find relevant results in the scholarly literature review raises certain questions about the challenges that HR professionals face, such as whether this a subject matter that does not concern the academic community, or whether it represents an issue that academia approaches from different viewpoints and using different keywords.

In order to investigate the lack of data in academic literature, we contacted other researchers through Researchgate.comand the HR section of the Spanish association ACEDE (Scientific association of economics and business management) requesting their cooperation to gather relevant data. As a result of this consultation, with a good response rate from international researchers, we have accessed the following reports and articles written by consulting firms and HR executive manager associations: 
- Websites of the main HRM manager associations:

- International:

- WFPMA (World Federation of People Management Associations)

- SHRM (Society for Human Resource Management)

- European:

- EAPM (European Association for People Management)

- National:

- APD (Asociación para el Progreso de la Dirección) [Association for progress in management]

- ADEIPE (Asociación Española de Dirección y Desarrollo de Personas) [Spanish association of people management and development]

- Internationally and nationally renowned consulting firm websites:

- Boston Consulting Group

- Price Waterhouse Coopers

○ Deloitte

- Garrigues

We located a large collection of reports from these sources $(\mathrm{N}=33)$, as this issue has been widely covered by professional associations and prestigious consulting firms in the human resources field. We compiled a summary sheet selecting the pertinent data, figures and graphs:

- Background data: year, methodology, data source, scope, countries, respondent profile and position.

- Data and charts related to the challenges.

- Data on programs and human resource management tools used as a solution to address these challenges.

From each summary sheet we categorized the different challenges and proposed solutions, then classifying the information in an excel table. After detailed analysis of the information obtained, we selected the 24 reports that provided relevant data for our study.

For the "Key challenges for HR managers" question we gathered data from 20 reports, comprising more than 34,000 responses from HR professionals. In each of these reports we compiled a list of the 5-7 most important challenges. We subsequently analyzed the differences between short and medium/long term relevance, given that 12 of the 20 reports provide data on short-term challenges (more than 17,000 responses), and 13 provide information medium/long term challenges (26,500 responses from practitioners).

Having identified the importance placed on challenges within the different reports analyzed (inter-report priority), we also analyzed the intra-report priority, examining a longitudinal series of six reports (over 23,000 responses) published annually since 2008 by the same HR consulting firm. This analysis allows us to draw conclusions from a set of reports that share the same data collection methodology and use the same terminology.

To address the question "What programs are being prioritized in people management and do these programs correspond to those traditionally called High Involvement Work Programs (HIWP)" we used data from 16 of the 24 original reports, covering more than 25,000 responses from HR managers worldwide. These reports identify concrete solutions implemented to address the various challenges. 
Finally, for the question "To what extent do the implemented programs respond to the challenges identified", our methodology was to draw up a double entry table of solutions/challenges, which was sent out to two experts in the field. These experts were asked to relate each implemented solution to the challenges that it could address, with an established maximum of two challenges per solution.

\section{Description of reports used}

Our literature review in the field of gray literature has provided us with two different types of resources:

- Series. Reports written periodically over several years, which take repeated looks at various issues relevant to the HR function and the challenges that it faces.

- One-off reports, which gather the opinions of human resource managers about a particular topic at a given moment.

Our first resource, the series, provide us with an analysis framework repeated over several years, a longitudinal view that highlights the evolution of the topic under study subject matter over the time series, making it a particularly useful data source for our analysis.

In this category are reports by:

- World Federation of People Management Associations (WFPMA), in collaboration with Boston Consulting Group (BCG) "Creating people advantage" series: 2010, 2011, 2012, 2013 and 2014-2015. This series of reports, launched in 2007, of which the latest edition we analyzed (2014-2015) is the eighth, examines the key trends influencing HRM year over year. The series is based on a survey of a large number of HR managers $(2,000$ to 4,000$)$ from a wide range of sectors in more than 30 countries worldwide and is complemented by a series of in-depth interviews to a selected group of between 30 and $50 \mathrm{HR}$ managers in each edition.

- Center for Advanced Human Resource Studies (CAHRS) - Cornell University ILR School. "Chief Human Resource Officer Survey" series: 2010, 2011, 2012. In 2009 the Center for Advanced Human Resource Studies at Cornell University launched a series of studies aimed at identifying the main requirements for chief human resource officers (CHRO), and discovering gaps in knowledge and tools that prevent them from responding to the challenges they face. The latest study of the series, published in 2013, corresponds to the results of the 2012 survey, directed at companies from the Fortune 500 list.

- PWC - "Annual Global CEO Survey" series: 2013, 2014 and 2015. The "Global CEO Survey", which was published in 2015, is the eighteenth edition of an annual survey composed of more than 1,000 interviews with presidents and CEOs of companies from more than 70 countries including Spain. These reports reflect the opinions of management on the progress of the world economy, growth prospects for companies (revenue, employment, investments, etc.), their main concerns for the years ahead, and market trends that will shape the future of the companies, as well as the strategies presidents and CEOs adopt to address these trends, including human resource management.

- Society for Human Resource Management (SHRM):

- "Challenges Facing HR Over the next 10 years" series: 2010 and 2012 reports. This two-part series questioned more than $350 \mathrm{HR}$ professionals around the world, all members of the SHRM, on what challenges they would face over the next 10 years (2020 and 2022), when the so-called Millennials, the generation born between 1980 and 2000, would represent the majority of the workforce.

- "Employee Job Satisfaction and Engagement survey of U.S. employees" series: 2013 and 2014. The aim of this series of reports, running since 2002 and focused on the US, is to identify the factors that affect employee satisfaction in general and workplace participation. This information provides data on employee preferences and highlights key areas organizations should take into account when developing organizational improvement initiatives. 
- "Employee Recognition Programs" series: 2013 and 2015. The aim of this series of reports, launched in 2011 and with five published issues to date, is to gather data from HR leaders and professionals, all SHRM members worldwide, identify trends regarding the challenges they face and the strategies that help them meet those challenges. These reports carry out detailed evaluation of the use and importance of recognition programs as a tool to foster employee engagement and retain talent.

- "Workplace Forecast" series: 2011 and 2013. These reports, published every two years since 2003, are based around a survey of HR professionals worldwide, all SHRM members, on their views on key issues affecting the workplace in the years ahead. The report is divided into four main sections covering demographics and society, economy and employment, politics and public law, and science and technology. The survey also asks HR professionals what actions their organizations are taking, or plan to take, to address these trends, changes and challenges.

- "Special Expertise Panels. Future Insights" series: 2012 and 2014. This series began in 2005. On each panel, and on each subject matter, Human Resource experts and opinion leaders contribute their views on the trends and forefront ideas of the profession. These expert "future insights" are used by SHRM as an agenda for activities, research and services, and since 2005, when 12 panels were initially defined, both the panels and the issues chosen for debate have been annually reviewed and updated. In the last, 2014 edition, the panels were reduced to six: "ethics", "global", "HR disciplines", "Labor relations", "technology and HR management " and " workplace diversity and inclusion."

- Deloitte. "Global Human Capital Trends" series: 2013, 2014 and 2015. It presents the global trends guiding decision making in business and, specifically, in human resources. Each report provides data on these trends in both global markets and on the local level of each participating country, through the results of a survey involving more than 1,300 companies and HR professionals from around 60 countries-

- Garrigues. "Estudio de Prioridades y Tendencias: Recursos Humanos" [Study of priorities and trends: human resources], 2014 and 2015. These reports set out the most relevant trends and priorities in the field of human resources each year. They are put together by Garrigues' Human Capital Services department from contributions by HR managers and directors from over 200 companies of different sizes and types located in Spain: local companies, subsidiaries of international groups and Spanish multinationals.

From our second type of search results, the "one-off reports" we selected one-off studies from different consulting firms and associations in the field of Human Resources:

- WFPMA -PWC "Encuestasobredesafíosglobales de RRHH: Ayer, hoy y mañana” [Survey of global HR challenges: yesterday, today and tomorrow]. 2005.

- SHRM:

- "Leading now, leading the future: What senior HR leaders need to know". 2009

- “2012 CSR human resources compensation survey participant summary”. 2011

- EAPM (European Association for People Management)- BCG - "The future of HR in Europe. Key Challenges through 2015”. 2010

- The Economist Intelligence Unit (sponsored by IBM and Oracle). "CEO perspectives. How HR can take on a bigger role in driving growth". 2012

- World Economic Forum "Global talent risk. Seven responses". 2012 
- People Excellence Consulting and Asociación para el Progreso de la Dirección [Association for progress in management] (APD). "Odisea 2017. Gestionando personas en tiempos de cambio" [2017 Odyssey. Managing people in times of change]. 2014

As regards the data obtained from scientific literature, as already mentioned, we only located one article that answers our research question and it must be noted that it focuses on multinationals, a fact that will be shown below to be significant in our research findings and limitations of our study.

Annex A, B and C shows the most relevant descriptive data of the 24 reports we finally used in our analysis:

- Origin: Scientific literature (SL) or gray literature (GL)

- Type: a series of reports (series) or one-off report (one-off)

- Year: Year of publication / year data was collected

- $\quad$ Editor

- Report title

- Sample size

- Scope: Global, US, Europe, Spain

- Data provided for our study (current challenges, future challenges, tools)

\section{Analysis and discussion of the challenges that affect human resources managers}

The results of our analysis are presented below, first identifying the external and internal factors which according to the articles reviewed have the greatest impact on human resources management, and therefore are key in identifying the challenges that must be met by HR managers in organizations (Figure 2).

\subsection{External an internal factors}

Among external factors, the economic landscape has the greatest impact on people management, but increasing business competitiveness, legislative changes and the introduction of new technology and media also affect Human Resource Management activity in different ways. The evolution and interaction of each of these aspects create new opportunities for innovation and growth, but also generate new challenges (Deloitte, 2014; PWC, 2014).

The introduction of new information technologies has transformed the workplace, and the use of mobile devices being particularly important (Deloitte, 2014). This technology has transformed recruitment systems, the world of training and analytics, and even the way we work, blurring the boundaries between work and rest: employees are online $24 / 7$, and inundated with information, messages and communications, which also implies a need to adapt their skills (Deloitte, 2015).

The internal factors with the greatest impact on HR departments are strategy implementation, management of new business requirements, new models of work, the need to increase productivity, reduction of resources and the increasing incorporation of millennials into the labor market (APD \& People-excellence-consulting, 2014; Garrigues, 2014, 2015).

Analyzing strategy implementation in detail reveals that HR departments are becoming increasingly important within companies, taking on responsibility for aligning the performance of each employee with the corporate mission and objectives (Ulrich \& Dulebohn, 2015). However, it is noteworthy that according to CEOs (Chief Executive Officers), HR managers have not completed their transition from administrator to strategic partner (CAHRS, 2013; EIU, 2012). The reasons given for this disparity are that the latter are still more focused on process rather than strategy, don't understand the business well enough, and their level of training is not of the same caliber as that of other managers, which results in their behaving like independent advisors rather than full members of the management team (EIU, 2012). 


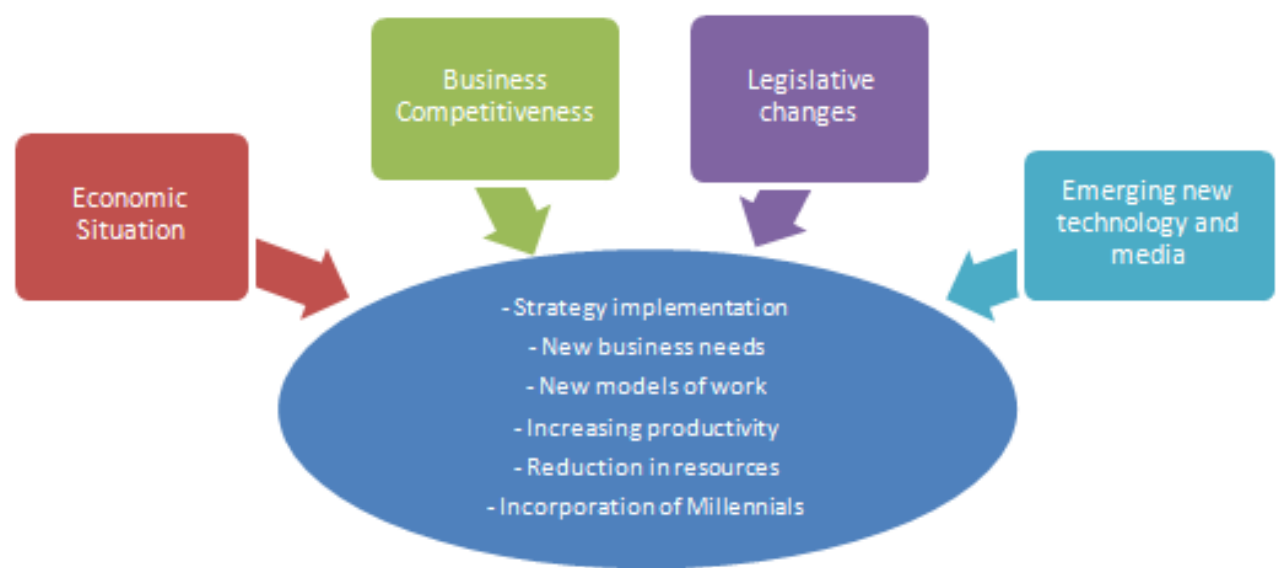

Figure 2. External and internal constraints with greatest impact on Human Resource Management, that influence the challenges (Prepared from PWC, 2013, 2014, 2015)

\subsection{Challenges}

Having explored the most important external and internal constraints, we turn next to the challenges that have been identified in the documents studied and the solutions companies have adopted to address them.

After describing the challenges that HR managers cite as most important, we conducted an inter-report analysis (collating the views of different report series) of the priority given to these challenges on a global level, in both the short term and in the future. Once the inter-report analysis has been conducted, we analyzed how the priority level of these challenges evolves, but at an intra-report level: conducting an in-depth study of one series of reports that provides a longitudinal view over several years.

To identify the challenges, as mentioned in the methodology section, we selected the 20 reports containing relevant data, and compiled the 5-7 most important challenges from each. Taking into account both the short and medium/long term, this selection gives us a total of 20 challenges, which are shown in Table 1.

\begin{tabular}{|l|l|}
\hline Code & Challenges \\
\hline 1 & Talent management \\
\hline 2 & Improving leadership development \\
\hline 3 & Employee engagement \\
\hline 4 & Retaining the best employees \\
\hline 5 & Total rewards/compensation and benefits \\
\hline 6 & Management of corporate culture \\
\hline 7 & Executive succession planning \\
\hline 8 & Training - Learning and people development \\
\hline 9 & Organizational effectiveness \\
\hline 10 & Measuring workforce performance \\
\hline 11 & Innovation. Selection and use of HR technology/HR analytics \\
\hline 12 & Improving employer branding \\
\hline 13 & Change management \\
\hline 14 & Transforming HR into a strategic partner \\
\hline 15 & Recruitment and selection \\
\hline 16 & Managing work-life balance \\
\hline 17 & Legal and administrative issues \\
\hline 18 & Labour relationship \\
\hline 19 & Employees mobility \\
\hline 20 & Strategic worforce planning \\
\hline
\end{tabular}

Table 1 . The 20 most common challenges, ranked by short-term priority (Compiled by authors using data from reports under study) 
To observe the priority given to these challenges in the short term, Figure 3 shows a breakdown of how often these challenges are cited in the 12 reports that provide information.

As we can see, the most pressing challenge is "Talent management", which appears in 10 of the reports. Second is "Improving leadership development" and in joint third place, with 6 mentions, "Employee engagement" and "Retaining the best employees". "Total rewards/compensation and benefits" appears in fourth position, and joint fifth are "Management of corporate culture" and "Executive succession planning", mentioned in 4 reports.

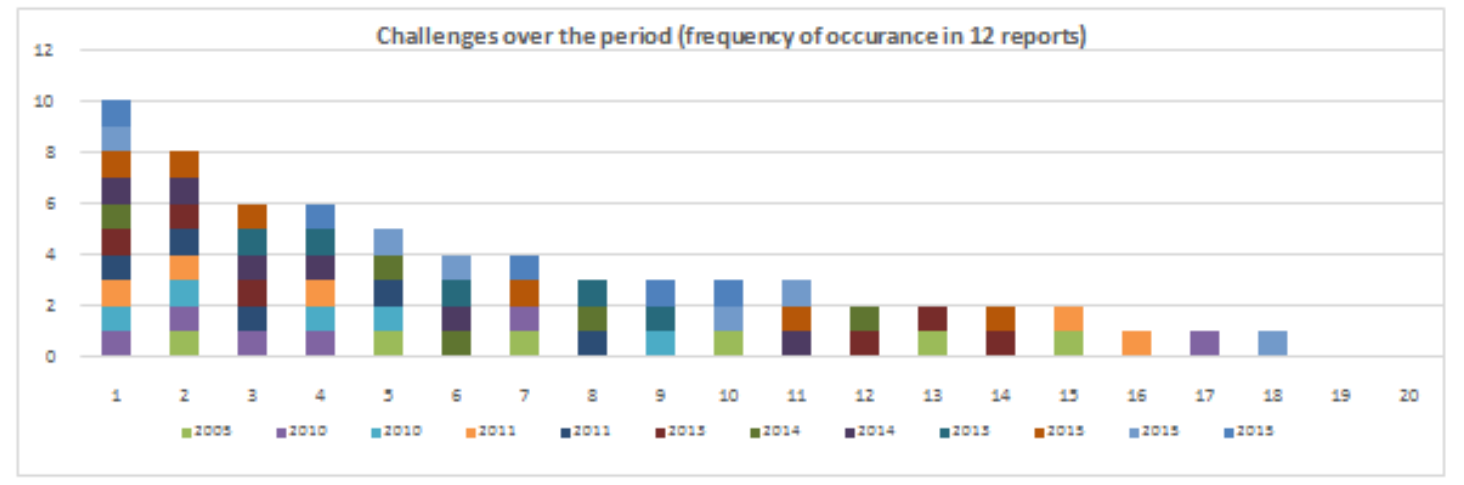

Figure 3. Challenges over the period (Compiled by authors. Key: x-axis shows the different challenges as ranked in Table 1)

On the other hand, the data in Figure 4, showing future challenges, indicates that in the medium/long term HR managers place most importance on "Talent management" (mentioned in 14 of 15 reports), "Improving leadership development" (12 reports), and thirdly "Recruitment and selection". "Retaining the best employees" appears next, and "Employee engagement" and "Transforming HR into a strategic partner" are in joint fifth position.

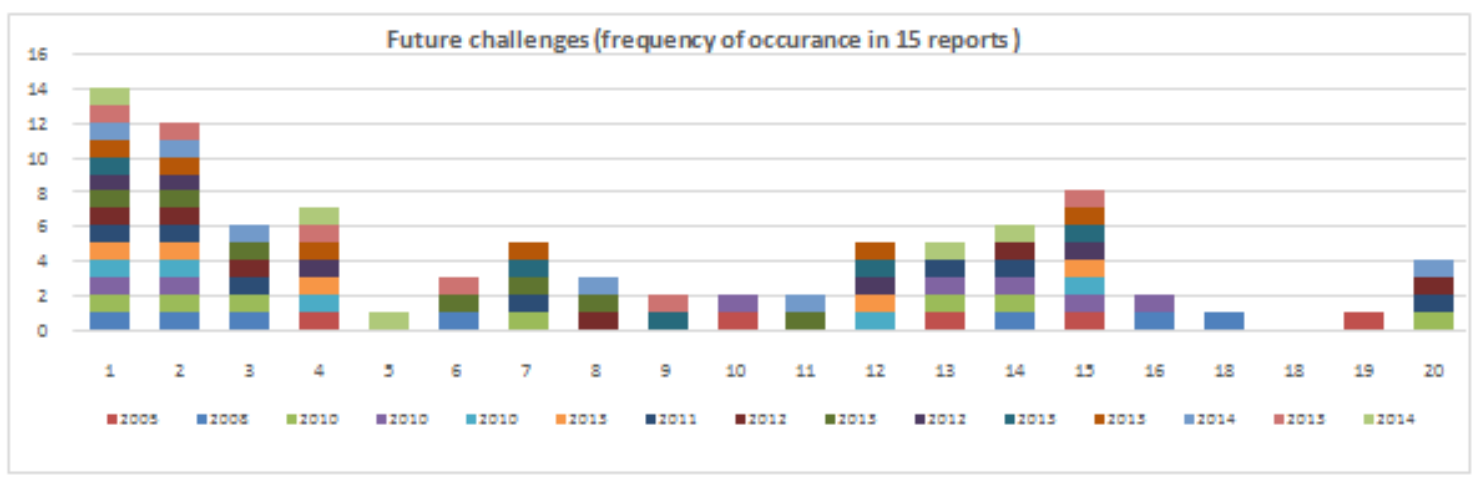

Figure 4. Future challenges. (Compiled by author. Key: x-axis shows the different challenges as ranked in Table 1)

Comparing the short-term and medium/long term challenges in the two previous figures, our key observations are listed below:

- "Talent management" and "Leadership" remain top priorities whether HR managers focus on immediate or longer-term challenges.

- "Retaining the best employees" and "Employee Engagement" are assigned less priority (passing from third to fourth and fifth place respectively), but are still amongst the most important concerns.

- Challenges related to "Total rewards/compensation and benefits", "Training - learning and people development" and "Measuring workforce performance" are no longer a top priority in the medium/long term. 
- "Recruitment and selection", not a pressing concern when HR managers are focused on the short term, jumps to third place when they consider medium/long term challenges.

As a summary, the Table 2 lists the most important challenges ranked by future importance, according to the analyzed reports. We indicate first the frequency $(\mathrm{f})$ - in how many reports they are mentioned-, and afterwards, in brackets, their level of priority (p) or importance.

\begin{tabular}{|l|l|c|c|}
\hline \multicolumn{2}{|l|}{ CHALLENGES } & $\begin{array}{l}\text { Short term } \\
\text { (f/p) }\end{array}$ & Future (f/p) \\
\hline 1 & Talent management & $10\left(1^{\text {st }}\right)$ & $14\left(1^{\text {st }}\right)$ \\
\hline 2 & Improving leadership development & $8\left(2^{\text {nd }}\right)$ & $12\left(2^{\text {nd }}\right)$ \\
\hline 15 & Recruitment and selection & & $8\left(3^{\text {rd }}\right)$ \\
\hline 4 & Retaining the best employees & $6\left(3^{\text {rd }}\right)$ & $7\left(4^{\text {th }}\right)$ \\
\hline 3 & Employee engagement & $6\left(3^{\text {rd }}\right)$ & $6\left(5^{\text {th }}\right)$ \\
\hline 14 & Transforming HR into a strategic partner & & $6\left(5^{\text {th }}\right)$ \\
\hline 5 & Total rewards/compensation and benefits & $5\left(4^{\text {th }}\right)$ & \\
\hline 6 & Management of corporate culture & $4\left(5^{\text {th }}\right)$ & \\
\hline 7 & Executive succession planning & $4\left(5^{\text {th }}\right)$ & \\
\hline
\end{tabular}

Table 2. Differences between priority level of challenges in short and long term (Compiled by authors)

Analyzing this data we can conclude, firstly, that HR managers' concerns about talent management and leadership in both the short and long term indicate their viewpoint that these are not challenges that will disappear in the coming years, regardless of the tools in place to address them. Addressing them successfully therefore requires dedication, commitment and ongoing trend analysis.

This same approach can be applied to challenges associated with retaining the best employees and employee engagement, given that they also remain a high priority in both the short and medium/long term. This is consistent with the fact that optimal talent management should involve retaining the best employees, and their commitment to the company (Christensen Hughes \& Rog, 2008).

In contrast, HR managers see "compensation", "training" and "measuring workforce performance" as being less important in the future. This may be because they are confident that they possess the necessary training and tools to meet these challenges in the short term. This is not the case with "Recruitment and selection", however, which becomes considerably more important, moving from fifteenth place in the short-term analysis to third place regarding medium-term concerns.

To explain this significant jump it is useful to look at three factors. On the one hand, the major economic crisis affecting companies and sectors across the board means that in the short-term recruitment is not important compared to other, cost-related factors, such as "compensation" and "measuring workforce performance". Another aspect is the fact that new technologies are changing the hiring process and landscape, provoking a need to reshape the recruitment and selection procedures currently in place in companies. Add to this the foreseeable need to increase the workforce in the medium term (PWC, 2015) and it becomes clear why this challenge increases in priority in the medium/long term.

Also worth highlighting is the increased importance of "Transforming HR into a strategic partner", in line with recommendations made by CEOs regarding changes in the HR function (CAHRS, 2013; EIU, 2012).

Having identified the main concerns among the different reports selected, termed here "inter-report" relevance, the next step is to analyze whether the same priority is allocated when we analyze the evolution of "intra-report" relevance.

As set out in the methodology section, for this analysis we have chosen to examine a single series of reports to provide a significant longitudinal view, and to avoid any bias that might occur in selecting reports with differing data collection methodology, and/or terminology. 
Applying these criteria, we have selected the series "Creating People Advantage" for the intra-report analysis and our findings are shown in Table 3.

\begin{tabular}{|c|c|c|c|c|c|c|c|c|}
\hline \multirow{2}{*}{\multicolumn{2}{|c|}{\begin{tabular}{|l} 
Scope \\
According to Table 1)
\end{tabular}}} & \multirow{3}{*}{$\begin{array}{l}\text { Challenge } \\
\text { (according to } \\
\text { "Creating people } \\
\text { advantage" series) }\end{array}$} & \multirow{3}{*}{\begin{tabular}{|l|} 
global \\
2008 \\
(BCG, \\
2008) 30 \\
\end{tabular}} & \multirow{3}{*}{\begin{tabular}{|l|} 
global \\
2009 \\
(BCG \& \\
WFPMA, \\
2010) \\
\end{tabular}} & \multirow{3}{*}{\begin{tabular}{|l|} 
global \\
2010 \\
(BCG \& \\
EAPM, \\
2011) \\
\end{tabular}} & \multirow{3}{*}{\begin{tabular}{|l} 
global \\
2011 \\
(BCG \& \\
WFPMA, \\
2012)
\end{tabular}} & \multirow{3}{*}{\begin{tabular}{|l|} 
Europe \\
2012 \\
(BCG \& \\
EAPM, \\
2013) \\
\end{tabular}} & \multirow{3}{*}{\begin{tabular}{|l} 
global \\
2013-2014 \\
(BCG \& \\
WFPMA, \\
2015)
\end{tabular}} \\
\hline & & & & & & & & \\
\hline Code & Challenge & & & & & & & \\
\hline 2 & $\begin{array}{l}\text { Improving leadership } \\
\text { development }\end{array}$ & Leadership & 2 & 2 & 2 & 2 & 1 & 1 \\
\hline 1 & Talent management & Talent and management & 1 & 1 & 1 & 1 & 1 & 2 \\
\hline 6 & $\begin{array}{l}\text { Management of } \\
\text { corporate culture }\end{array}$ & Behavior and culture & 4 & & & & & 3 \\
\hline 20 & $\begin{array}{l}\text { Strategic workforce } \\
\text { planning }\end{array}$ & HR and people strategy & & & & & & 4 \\
\hline 3 & Employee engagement & Employee engagement & & 4 & 4 & 4 & & 5 \\
\hline 11 & $\begin{array}{l}\text { Innovation. Selection } \\
\text { and use of HR } \\
\text { technology/HR analytics }\end{array}$ & $\begin{array}{l}\text { Strategic workforce } \\
\text { planning (and reporting- } \\
\text { HR analytics) }\end{array}$ & & 3 & 5 & 3 & 2 & 6 \\
\hline 10 & $\begin{array}{l}\text { Measuring workforce } \\
\text { performance }\end{array}$ & $\begin{array}{l}\text { Career models and } \\
\text { competencies }\end{array}$ & & & & & & 7 \\
\hline$>20$ & HR communication & HR communication & & & & & 5 & 8 \\
\hline 9 & $\begin{array}{l}\text { Organizational } \\
\text { effectiveness }\end{array}$ & $\begin{array}{l}\text { Performance } \\
\text { management }\end{array}$ & & & & & & 9 \\
\hline 8 & $\begin{array}{l}\text { Training - Learning and } \\
\text { people development }\end{array}$ & Training and learning & & & & & & 10 \\
\hline 14 & $\begin{array}{l}\text { Transforming HR into a } \\
\text { strategic partner }\end{array}$ & $\begin{array}{l}\text { Transforming HR into a } \\
\text { strategic partner }\end{array}$ & 3 & 5 & 3 & & & \\
\hline 16 & $\begin{array}{l}\text { Managing work-life } \\
\text { balance }\end{array}$ & $\begin{array}{l}\text { Managing work-life } \\
\text { balance }\end{array}$ & 5 & & & 5 & & \\
\hline$>20$ & Demography & Demography & 6 & & & & & \\
\hline$>20$ & Continuous learning & Continuous learning & 7 & & & & & \\
\hline$>20$ & Managing globalization & Managing globalization & 8 & & & & & \\
\hline 15 & $\begin{array}{l}\text { Recruitment and } \\
\text { selection }\end{array}$ & $\begin{array}{l}\text { Recruiting: branding, } \\
\text { hiring, and onboarding }\end{array}$ & & & & & 3 & \\
\hline 7 & $\begin{array}{l}\text { Executive succession } \\
\text { planning }\end{array}$ & $\begin{array}{l}\text { Diversity and generation } \\
\text { management }\end{array}$ & & & & & 4 & \\
\hline
\end{tabular}

Table 3. Intra-report evolution of priority level of future challenges (BCG, "Creating People Advantage" series)

Table 3 shows the ten most important challenges included in this series of reports, launched in 2008. The code used in the first column refers to the result obtained in the previous inter-report ranking.

The importance of leadership and talent management for HR professionals is confirmed by the fact that in this analysis they remain at the top, while the priority assigned to other issues fluctuates in different editions of the report.

The origin of concerns about talent management lies in the need for companies to apply their skills in a more innovative way, making it critical to possess the optimal mix of talent, and the ability to alter the mix depending on the business needs of the company (PWC, 2015).

The topic is sufficiently important to merit in an in-depth analysis by the World Economic Forum. This organization, in collaboration with Boston Consulting Group (2011), analyzed in 2011 how companies should address the talent shortage that will likely occur on a global level in the future. The study proposes solutions based on evaluating more than 300 best practices in companies and countries around the world, and proposes the following policies for global talent management: 
1. Introduce strategic workforce planning

2. Facilitate migration to attract the right talent, by innovating immigration control systems or being more "migration-friendly"

3. Promote brain circulation to counter brain drain

4. Increase employability boosting skills levels via different education systems

5. Develop a talent pool

6. Encourage temporary or virtual mobility

7. Establish policies that harness underused talent in demographics such as women, older professionals, disadvantaged groups, and immigrants

Given the importance of this aspect, we analyze below whether HR managers' concern about talent is also shared by CEOs.

We analyzed data from PWC surveys directed at CEOs which describes their overview of future prospects and challenges they face at different levels, including HR-related issues, as is shown in Table 4.

\begin{tabular}{|l|l|l|l|}
\hline Year & Global challenges & $\begin{array}{l}\text { Challenges for the HR } \\
\text { function }\end{array}$ & $\begin{array}{l}\text { Actions to address the challenges } \\
\text { for the HR function }\end{array}$ \\
\hline 2013 & $\begin{array}{l}\text { Economic uncertainty, } \\
\text { measures to combat fiscal } \\
\text { deficits, volatile markets and } \\
\text { regulation. }\end{array}$ & $\begin{array}{l}\text { The availability of key skills is } \\
\text { one of the main business threats } \\
\text { for more than half of CEOs. } \\
77 \% \text { of CEOs said they would } \\
\text { change their talent management } \\
\text { strategy in 2013. }\end{array}$ & $\begin{array}{l}\text { Work on: } \\
\text { Culture } \\
\text { Abilities/skills } \\
\text { Connectivity } \\
\text { Cost control }\end{array}$ \\
\hline \multirow{2}{*}{2014} & $\begin{array}{l}\text { Technological advances, } \\
\text { demographic changes and } \\
\text { changes in the global economy } \\
\text { about the availability of key } \\
\text { skills.93\% recognized the need } \\
\text { for change, or were changing } \\
\text { their strategies to attract and } \\
\text { retain talent. }\end{array}$ & $\begin{array}{l}\text { Develop employee potential, give } \\
\text { internal talent a key role, redesign the } \\
\text { rewards and financial incentives model, } \\
\text { improve the effectiveness of senior } \\
\text { management, supervisors and line } \\
\text { managers. }\end{array}$ \\
\hline $\begin{array}{l}\text { Ohe main challenges are talent } \\
\text { suitable talent are first on the } \\
\text { list, followed by geopolitical } \\
\text { uncertainty }\end{array}$ & $\begin{array}{l}\text { shortage and the disruptive } \\
\text { effects of applied technology in } \\
\text { all areas of business and } \\
\text { companies. }\end{array}$ & $\begin{array}{l}\text { the company, harnessing new } \\
\text { technologies to improve operational } \\
\text { efficiency, data analysis and the } \\
\text { customer experience. }\end{array}$ \\
\hline
\end{tabular}

Table 4. CEOs' main concerns: general and regarding the HR function (PWC, 2013, 2014, 2015)

Although this table summarizes data from only the last three surveys, talent management has in fact been the main objective for strategic change in the HR function in every CEO survey conducted by PWC during the last six years (PWC, 2013). This insistence on the part of CEOs regarding talent also suggests that, despite their endeavors, the changes and solutions implemented to address this challenge are not working. This would seem to indicate the need for a new approach to the basics of talent management, to attract and retain the best people, organize them in the most effective way, to create a culture of engagement, and motivate employees to provide the highest possible value without relying solely on compensation (BCG \& EAPM, 2011; PWC, 2013).

The importance of this challenge for professionals is also reflected in academia, where it has generated a burgeoning body of knowledge in recent years (Thunnissen, Boselie \& Fruytier, 2013). This interest from academia stems from the need to increase the skill level of the workforce to compete in the era of smart economics (Beechler \& Woodward, 2009), as talent management has been linked to greater efficiency levels, lower staff turnover, higher commitment and growth. Along these lines, Talent management (TM), defined as a high performance work system, also impacts positively on the market value of organizations and ROA (LunaArocas \& Morley, 2015). 
Turning finally to multinationals, these kinds of companies face unique challenges, given the peculiarities involved in implementing global HRM strategies, and transferring them at the operational level to the different countries they operate in, each with their own cultures, regulations, etc. Moreover, a common strategy for all countries where a multinational operates would be unlikely to work, and customized solutions are needed (Hurn, 2014). In fact, even when identifying which programs could be considered high performance, researchers are sometimes influenced by cultural differences into setting different priorities for each country (Combs et al., 2006).

For these companies, the top priority is the need to align HR policies and programs across multiple locations, while the second most pressing concern regards labor negotiations in the host countries. Surprisingly, dealing with time differences is the third most urgent challenge (Ananthram \& Chan, 2013). Regarding expatriate employees, the biggest challenges are adapting to the new culture of the destination country, selecting employees with the optimal background profile and managing issues such as family unification, compensation and repatriation conditions (Ananthram \& Chan, 2013).

\subsection{Solutions adopted to meet challenges}

HR professionals lack a guidance manual on where to start or what measures to prioritize (BCG \& EAPM, 2013). In order to answer the question "What programs are being implemented in people management, paying particular attention to high involvement programs", this section will look at the specific actions that HR professionals put in place to respond to the challenges they face.

For this section we have used data from 16 reports focused on the operational level, exploring specific solutions implemented.

This research has uncovered a total of $33 \mathrm{HR}$ management programs. An initial observation is that the terms High Involvement Work Programs, practices or tools (HIWP), are not explicitly used in the reports analyzed.

Considering the above-mentioned lack of consensus among researchers in classifying HIWP (Marin-Garcia \& Conci, 2013), there is a need to confirm whether the programs that we identified as most important in the analyzed reports can be defined as HIWP. We looked at the list proposed by Perello-Marin and Ribes-Giner (2014) which compiled a total of 42 programs commonly used by academics researching this area between 2000 and 2012. From this comparison we found that all identified solutions correspond to HIWPs, proving that although this is a term that is not used expressly in the reports analyzed, companies use such programs on a regular basis on the deployment of the HR function, and HR managers are interested in HIWP as a tool to meet challenges in the short and medium/long term.

Nonetheless, it is important to highlight that in order to accurately classify these programs as HIWP, we would need more information on whether companies are using these tools in conjunction. This is because the distinguishing feature of and power underpinning such programs is their use as a "bundle" or system of interrelated programs, which creates a synergistic effect that contributes to significantly better results than individual use (Huselid, Jackson, \& Schuler, 1997). This synergistic effect and its positive impact on corporate performance, compared to an isolated use of the programs, has been extensively evaluated and supported by research (Combs et al., 2006).

After confirming that the data corresponds to HIWP, Table 5 shows these programs grouped according to the diagram proposed in the AMO model, and links each program with the challenges it addresses using the sequence explained in the methodology section. Analysis of this table shows that some strategic challenges, such as "Talent management", "Employee engagement" or "Measuring workforce performance" are widely reported at an operational level, while others are barely mentioned or don't appear at all.

This data reveals a gap between challenges identified and solutions implemented, very evident in challenges such as "Leadership", "Retaining the best employees" or "Transforming HR into a strategic partner." This disparity between priority level and tools available, which has been noted by other authors (García Carbonell, Martín 
Alcázar \& Sánchez Gardey, 2013; Nishii \& Wright, 2007; Rynes, Colbert \& Brown, 2002), is also suggested from information provided by CEOs, who maintain that making employees feel involved in the business is a cornerstone of guaranteeing commitment. When it comes to implementing this, however, they rarely practice what they preach; encouraging employees to participate actively in decision making is not common (PWC, 2013).

\begin{tabular}{|c|c|c|c|c|c|c|c|c|c|c|c|c|c|c|c|c|c|c|c|c|c|}
\hline \multirow[t]{2}{*}{ AMO } & \multirow[t]{2}{*}{ PROGRAMS } & 1 & 2 & 3 & 4 & \begin{tabular}{l|l}
5 \\
\end{tabular} & 6 & 7 & 8 & 9 & 10 & 11 & 12 & 13 & 14 & 15 & 16 & 17 & 18 & 19 & 20 \\
\hline & & 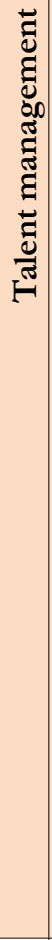 & 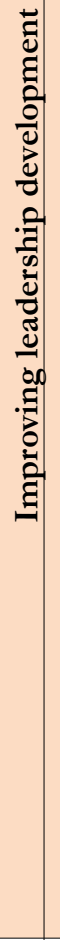 & 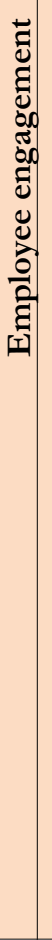 & 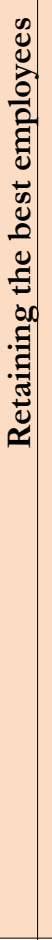 & 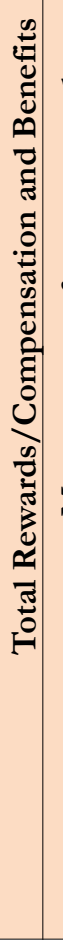 & 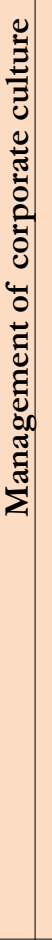 & 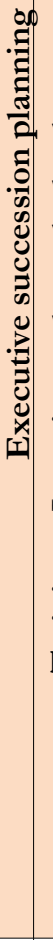 & 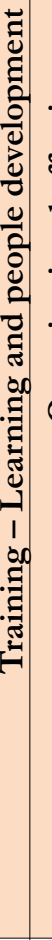 & 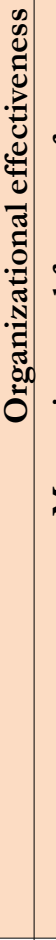 & 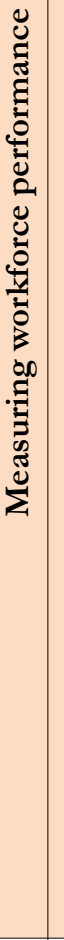 & 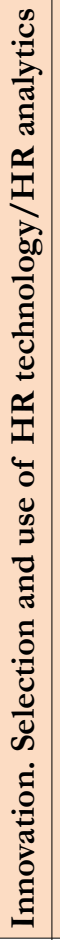 & 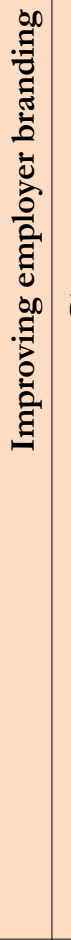 & 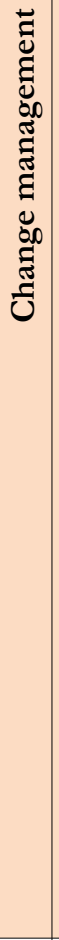 & 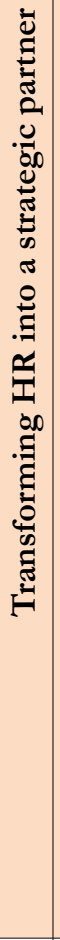 & 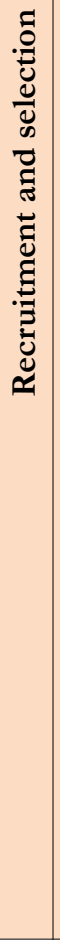 & 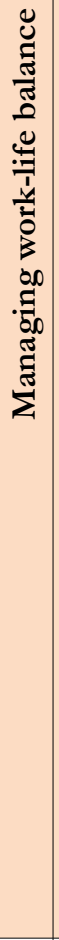 & 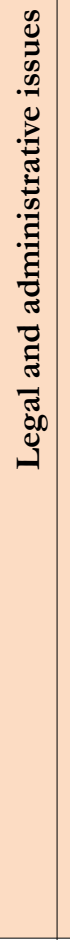 & 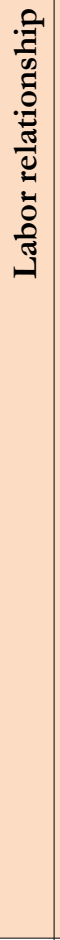 & 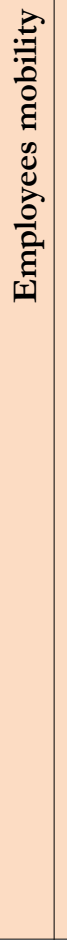 & 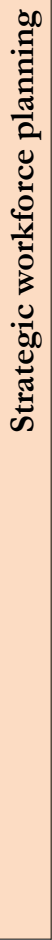 \\
\hline \multirow[t]{6}{*}{ A } & $\begin{array}{l}\text { Jobs Aligned with business } \\
\text { goals }\end{array}$ & & & & & & & & & $\mathrm{X}$ & & & & & $\mathrm{X}$ & & & & & & \\
\hline & $\begin{array}{l}\text { Frequent competence reviews } \\
\text { for employees and leaders }\end{array}$ & $\mathrm{X}$ & & & & & & & & & $\mathrm{X}$ & & & & & & & & & & \\
\hline & $\begin{array}{l}\text { Customization of employer } \\
\text { brand to target audience }\end{array}$ & & & & & & & & & & & & $\mathrm{X}$ & & & $\mathrm{X}$ & & & & & \\
\hline & $\begin{array}{l}\text { Recruitment based on scenarios } \\
\text { of business demand }\end{array}$ & & & & & & & & & & & & & & & $\mathrm{X}$ & & & & & $\mathrm{X}$ \\
\hline & $\begin{array}{l}\text { Job-specific training, aligned } \\
\text { with business strategy }\end{array}$ & & & & & & & & $\mathrm{X}$ & & & & & & $\mathrm{X}$ & & & & & & \\
\hline & $\begin{array}{l}\text { Skills gaps identified } \\
\text { systematically }\end{array}$ & $\mathrm{X}$ & & & & & & & & & & & & & $\mathrm{X}$ & & & & & & \\
\hline \multirow[t]{9}{*}{ M } & $\begin{array}{l}\text { Communicate and consolidate } \\
\text { organizational culture }\end{array}$ & & & & & & $\mathrm{X}$ & & & $\mathrm{X}$ & & & & & & & & & & & \\
\hline & $\begin{array}{l}\text { Assess employee performance } \\
\text { along defined criteria }\end{array}$ & & & & & & & & & & $\mathrm{X}$ & $\mathrm{X}$ & & & & & & & & & \\
\hline & $\begin{array}{l}\text { Systematic assessment and } \\
\text { review of high-potential } \\
\text { employees }\end{array}$ & $\mathrm{X}$ & & & & & & & & & $\mathrm{X}$ & & & & & & & & & & \\
\hline & Measuring HR performance & $\mathrm{X}$ & & & & & & & & & $\mathrm{X}$ & & & & & & & & & & \\
\hline & Coaching & $\mathrm{X}$ & $\mathrm{X}$ & & & & & & & & & & & & & & & & & & \\
\hline & $\begin{array}{l}\text { Recognition programs. E- } \\
\text { thanks }\end{array}$ & & & & $\mathrm{X}$ & & & & & & $\mathrm{X}$ & & & & & & & & & & \\
\hline & $\begin{array}{l}\text { Total Reward. Fair and flexible } \\
\text { according to performance }\end{array}$ & & & & & $\mathrm{X}$ & & & & & $\mathrm{X}$ & & & & & & & & & & \\
\hline & $\begin{array}{l}\text { Total Rewards. Better than } \\
\text { competitors }\end{array}$ & & & & $\mathrm{X}$ & $\mathrm{X}$ & & & & & & & & & & & & & & & \\
\hline & $\begin{array}{l}\text { Providing employees with } \\
\text { opportunities for career } \\
\text { advancement }\end{array}$ & $\mathrm{X}$ & & & $\mathrm{X}$ & & & & & & & & & & & & & & & & \\
\hline
\end{tabular}




\begin{tabular}{|c|c|c|c|c|c|c|c|c|c|c|c|c|c|c|c|c|c|c|c|c|c|c|c|c|}
\hline & $\begin{array}{l}\text { Long-term planning strategy } \\
\text { for managing talent and } \\
\text { leadership }\end{array}$ & $\mathrm{X}$ & & & & & & & & & & & & & & & $\mathrm{X}$ & & & & & & & \\
\hline & Offer job rotation & $\mathrm{X}$ & & & & & & & & & & & & & & & & & & & & & & \\
\hline & Job security & & & $\mathrm{X}$ & & & & & & & & & & & & & & & & & & & & \\
\hline $\mathrm{O}$ & $\begin{array}{l}\text { Jobs designed to be motivators } \\
\text { in themselves }\end{array}$ & $\mathrm{X}$ & & & $X$ & & & & & & & & & & & & & & & & & & & \\
\hline & $\begin{array}{l}\text { Providing employees the } \\
\text { opportunities to use skills and } \\
\text { abilities }\end{array}$ & $\mathrm{X}$ & & $\mathrm{X}$ & & & & & & & & & & & & & & & & & & & & \\
\hline & $\begin{array}{l}\text { Succession and mobility } \\
\text { planning }\end{array}$ & & & & & & & & $\mathrm{X}$ & & & & & & & & & & & & & & & \\
\hline & $\begin{array}{l}\text { Providing latest } \\
\text { tools/technology to maximize } \\
\text { work efficiency and } \\
\text { effectiveness }\end{array}$ & $\mathrm{X}$ & & & & & & & & & & X & & & & & & & & & & & & \\
\hline & $\begin{array}{l}\text { Establish teams with } \\
\text { multicultural backgrounds }\end{array}$ & & & $\mathrm{X}$ & & & & & & & & & & & & & & & & & & & & \\
\hline & Programs to share opinions & $\mathrm{X}$ & & $\mathrm{X}$ & & & & & & & & & & & & & & & & & & & & \\
\hline & $\begin{array}{l}\text { Institutionalize employee } \\
\text { feedback process }\end{array}$ & $\mathrm{X}$ & & $\mathrm{X}$ & & & & & & & & & & & & & & & & & & & & \\
\hline & $\begin{array}{l}\text { Monitoring and improving } \\
\text { employee satisfaction }\end{array}$ & $\mathrm{X}$ & & & & & & & & & & $x$ & & & & & & & & & & & & \\
\hline & $\begin{array}{l}\text { Contribution of work to } \\
\text { organization's business goals }\end{array}$ & & & $\mathrm{X}$ & & & & & & & & & & & & & $\mathrm{X}$ & & & & & & & \\
\hline & $\begin{array}{l}\text { Communication programs. } \\
\text { Improving relations with co- } \\
\text { workers }\end{array}$ & & & $\mathrm{X}$ & & & & & & & & & & & & & & & & & & & & \\
\hline & $\begin{array}{l}\text { Communication programs. } \\
\text { Improving relations with } \\
\text { managers }\end{array}$ & & $\mathrm{X}$ & $\mathrm{X}$ & & & & & & & & & & & & & & & & & & & & \\
\hline & $\begin{array}{l}\text { Recognition programs. } \\
\text { Recognition of direct } \\
\text { supervisor }\end{array}$ & & $\mathrm{X}$ & X & & & & & & & & & & & & & & & & & & & & \\
\hline & $\begin{array}{l}\text { Providing flexible work } \\
\text { arrangements - work-life } \\
\text { balance }\end{array}$ & & & & & & & & & & & & & & & & & & $\mathrm{X}$ & & & & & \\
\hline & Leadership model & & $\mathrm{X}$ & & & & & & & & & & & & & & & & & & & & & \\
\hline & Gamification at work & & & & & & & & & & & & & & & & & & & & & & & \\
\hline & $\begin{array}{l}\text { PROGRAMS USED TO } \\
\text { SS CHALLENGES }\end{array}$ & 14 & 4 & 9 & 4 & & & & 1 & 1 & 2 & 8 & & & 1 & 0 & 5 & 2 & 1 & 0 & 0 & & & 1 \\
\hline
\end{tabular}

Table 5. Solutions adopted and their relative challenges

\section{Conclusions}

Having explored the main challenges facing company HR managers, and taking into account the internal and external constraints that affect them, we have reached the following conclusions:

- The challenges most frequently mentioned by HR professionals are talent management and leadership. Concern about talent management is shared by CEOs.

- The priority of challenges differs significantly according to whether HR managers associate them with the short or long term, in line with the evolution of both external and internal constraints which companies face, although talent management and leadership remain top priorities in both the short and long term.

- The importance of talent management for both CHROs and CEOs, and the fact that this concern has remained constant over the years, suggests an inability within companies to meet this challenge.

Below we describe our conclusions regarding solutions implemented to address these challenges: 
- The term "high involvement work program" (HIWP) is not yet in widespread use in studies conducted by business organizations or major consulting firms in the HR field.

- Although the term HIWP is not explicitly used, these programs are systematically used by HR managers in companies to meet challenges.

- The programs adopted by companies are useful in the areas of Talent management, Leadership and Employee engagement, the top challenges cited.

- We have observed that certain challenges have a much narrower range of implemented programs, suggesting a possible gap between the challenges identified and implemented solutions.

These conclusions are relevant in the professional arena as they provide professionals with an overview of the challenges they face, so they can plan optimal HR management programs and work methods geared towards success, and identify improvement opportunities. In the academic sphere, our study opens possible future research lines that may contribute to the development of the profession, as we offer clear data on HR management viewpoints and the challenges they face. Moreover, identifying research lines that genuinely address the concerns of professionals could help reduce the gap that some researchers have identified between the academic and professional spheres (Cohen, 2007; Kaufman, 2012; Stone \& Deadrick, 2015).

Our conclusions are not without limitations, however. First, the type of information on which our study is based is not from the academic sphere, and has not therefore been subjected to peer review, which could cause some reservations. Additionally, using secondary data, and being therefore unable to control either the questions or the breakdown of information by size, country, activity, etc., means we cannot exert influence over the data to analyze. In addition, all reports are based on the opinions of senior management, but as various authors have noted, for "real human resource practices" and solutions that are implemented in organizations, the original data needs to come from employees rather than managers (Nishii, Lepak, \& Schneider, 2008), or at least from both sources (Bowen \& Ostroff, 2004; Guest, 2011; Paul \& Anantharaman, 2003; Wright \& Boswell, 2002). Finally, inter-report data analysis gives the same weight to reports presenting worldwide data as to reports providing data from a single continent, or even a single country (the US and Spain). This method introduces limitations in our study as there exist differences between countries and continents, not only regarding the challenges themselves, but also regarding priorities (Brewster, 2004), as does a possible Anglo-bias due to the greater availability of English language data.

\section{Future lines of research}

With the aim of bringing the academic model to the professional sphere, future research could explore the challenges that professionals face using methodological tools from scientific research, thus avoiding the limitations discussed in the previous section. Additionally, our analysis has not explored employee perceptions, so it would be useful to take a more in-depth look at this area and seek their feedback on the suitability of programs designed to deal with the challenges. Finally, our research reveals areas already being addressed from an academic perspective, such as talent management, leadership improvement and employee engagement, and these clearly represent a challenge for professionals, so we must continue to evaluate the available tools and best methodologies that enable professionals to improve the solutions adopted in organizations.

\section{Declaration of Conflicting Interests}

The authors declared no potential conflicts of interest with respect to the research, authorship, and/or publication of this article.

\section{Funding}

The authors received no financial support for the research, authorship, and/or publication of this article. 


\section{References}

Ananthram, S., \& Chan, C. (2013). Challenges and strategies for global human resource executives: Perspectives from Canada and the United States. European Management Journal, 31(3), 223-233.

https://doi.org/10.1016/j.emj.2012.12.002

APD, \& People-excellence-consulting (2014). Odisea 2017. Gestionando personas en tiempos de cambio. Retrieved from http://peoplexcellence.com/wp-content/uploads/2014/06/Odisea_2017.pdf (Last access date: August 21st, 2017)

Appelbaum, E., Bailey, T., Berg, P., Kalleberg, A.L., \& Cornell, N.Y. (2000). Manufacturing Advantage: Why High- Perlormance Work Systems Pay Oft by. Academy of Management Review, 26(3), 459-462. https://doi.org/10.2307/259189

Arthur, J.B., \& Boyles, T. (2007). Validating the human resource system structure: A levels-based strategic HRM approach. Human Resource Management Review, 17(1), 77-92. https://doi.org/10.1016/j.hrmr.2007.02.001

Bailey, T. (1993). Organizational Innovation in the Apparel Industry. Industrial Relations: A Journal of Economy and Society, 32(1), 30-48. https:// doi.org/10.1111/j.1468-232X.1993.tb01017.x

BCG (2008). Creating People Advantage. Cómo afrontar los desafíos de RRHH en todo el mundo hasta 2015. Retrieved from: http://www.thebostonconsultinggroup.es/documents/file8904.pdf (Last access date: September 21st, 2017)

BCG, \& EAPM (2010). The Future of HR in Europe. Key Challenges Through 2015. Retrieved from: https://www.bcg.com/documents/file15033.pdf (Last access date: September 21st, 2017)

BCG, \& EAPM (2011). Creating People Advantage 2011. Time to Act: HR Certainties in Uncertain Times. Retrieved from: http://www.bcg.de/documents/file87639.pdf (Last access date: September 21st, 2017)

BCG, \& EAPM (2013). Creating people advantage 2013. Lifting HR pratices to the next level. Retrieved from: http://www.bcg.de/documents/file147615.pdf (Last access date: September 21st, 2017)

BCG, \& WFPMA (2010). Creating People Advantage 2010. How Companies Can Adapt Their HR Practices for Volatile Times. Retrieved from: https://www.bcg.com/documents/file61338.pdf (Last access date: September 21st, 2017)

BCG, \& WFPMA (2012). Creating People Advantage 2012. Mastering HR Challenges in a Two-Speed World. Retrieved from: https://www.shrm.org/hr-today/trends-and-forecasting/research-andsurveys/Documents/BCG Creating People Advantage Oct 2012.pdf (Last access date: September 21st, 2017)

BCG, \& WFPMA (2015). Creating people advantage 2014-2015. How to set up great HR functions: Connect, Priorize, Impact. Retrieved from: http://www.wfpma.com/sites/wfpma.com/files/BCG Creating People Advantage 20142015.pdf (Last access date: September 21st, 2017)

Beechler, S., \& Woodward, I.C. (2009). The global “war for talent”. Journal of International Management, 15(3), 273-285. https://doi.org/10.1016/j.intman.2009.01.002

Bowen, D.E., \& Ostroff, C. (2004). Understanding HRM-Firm Performance Linkages: The Role of the "Strengt" of the HRM System. Academy of Management Review, 29(2), 203-221. https://doi.org/10.5465/amr.2004.12736076

Boxall, P. (2012). High-performance work systems: What, why, how and for whom?. Asia Pacific Journal of Human Resources, 50(2), 169-186. https://doi.org/10.1111/j.1744-7941.2011.00012.x

Brewster, C. (2004). European perspectives on human resource management. Human Resource Management Review, 14(4), 365-382. https://doi.org/10.1016/j.hrmr.2004.10.001

CAHRS (2010). From bunker to building: Results from the 2010 chief human resource officer. Retrieved from: http://files.eric.ed.gov/fulltext/ED516984.pdf (Last access date: September 21st, 2017)

CAHRS (2011). The 2011 CHRO Challenge: Building organizational, Functional, and Personal Talent. Retrieved from: https://sc.edu/study/colleges schools/moore/documents/ces research/chro 2011.pdf (Last access date: September 21st, 2017) 
CAHRS (2013). HR in the C-Suite: CAHRS 2012 Chief Human Resource Officer. Survey Results. Retrieved from: https://sc.edu/study/colleges schools/moore/documents/ces research/chro 2012.pdf (Last access date: August 21st, 2017)

Christensen Hughes, J., \& Rog, E. (2008). Talent management: : A strategy for improving employee recruitment, retention and engagement within hospitality organizations. International Journal of Contemporary Hospitality Management, 20(7), 743-757. https://doi.org/10.1108/09596110810899086

Cohen, D.J. (2007). The very separate worlds of academic and practitioner publications in human resource management: Reasons for the divide and concrete solutions for bridging the gap. Academy of Management Journal, 50(5), 1013-1019. https://doi.org/10.5465/amj.2007.27151946

Combs, J., Liu, Y.M., Hall, A., \& Ketchen, D. (2006). How much do high-performance work practices matter? A meta-analysis of their effects on organizational performance. Personnel Psychology, 59(3), 501-528.

https://doi.org/10.1111/j.1744-6570.2006.00045.x

Deloitte (2013). Resetting Horizons. Human Capital Trends 2013. Retrieved from: http://www2.deloitte.com/content/dam/Deloitte/global/Documents/HumanCapital/dttl-hc-hctrendsglobal8092013.pdf (Last access date: September 21st, 2017)

Deloitte (2014). Global Human Capital Trends 2014. Engaging the 21st century workforce. Retrieved from: http://www2.deloitte.com/sa/en/pages/human-capital/articles/human-capital-trends-2014.html (Last access date: September 21st, 2017)

Deloitte (2015). Global Human Capital Trends 2015. Leading in the new world of work. Retrieved from: http://www2.deloitte.com/us/en/pages/human-capital/articles/introduction-human-capital-trends.html (Last access date: September 21st, 2017)

EIU (2012). CEO perspectives. How HR can take on a bigger role in driving growth. Retrieved from: http://www.ibm.com/solutions/files/V379497Q73917S31/ceo how hr can take on a bigger role in driving growt h.pdf (Last access date: August 21st, 2017)

García Carbonell, N., Martín Alcázar, F., \& Sánchez Gardey, G. (2013). A theoretical model about the double strategic fit of the HRM strategy: Employees perceptions as connector between formulated and implemented HR practices. Intangible Capital, 9(4), 991-1020. https://doi.org/10.3926/ic.431

Garrigues (2014). Estudio de Prioridades y Tendencias: Recursos Humanos 2014. Retrieved from: http://www.garrigues.com/doc/emags/Garrigues HCS Estudio de Prioridades/pubData/source/HCS PRIORIDA DES RRHH.pdf (Last access date: August 21st, 2017)

Garrigues (2015). Estudio de prioridades y tendencias. Recursos bumanos 2015. Retrieved from: http://www.garrigues.com/doc/emags/Garrigues HCS Estudio de Prioridades y/index.html\#/3/ (Last access date: August 21st, 2017)

Guest, D.E. (2011). Human resource management and performance: Still searching for some answers. Human Resource Management Journal, 21(1), 3-13. https://doi.org/10.1111/j.1748-8583.2010.00164.x

Hurn, J.B. (2014). The challenges facing international HRM in an increasingly globalised environment. Industrial and Commercial Training, 46(7), 371-378. https://doi.org/10.1108/ICT-06-2014-0041

Huselid, M.A. (1995). The impact of human-resource management-practices on turnover, productivity, and corporate financial performance. Academy of Management Journal, 38(3), 635-672. https://doi.org/10.2307/256741

Huselid, M.A., Jackson, S.E., \& Schuler, R.S. (1997). Technical and strategic human resource management effectiveness as determinants of firm performance. Academy of Management Journal, 40(1), 171-188. https://doi.org/10.2307/257025

Jiang, K., Lepak, D.P., Hu, J., \& Baer, J.C. (2012). How Does Human Resource Management Influence Organizational Outcomes? A Meta-analytic Investigation of Mediating Mechanisms. Academy of Management Journal, 55(6), 1264-1294. https://doi.org/10.5465/amj.2011.0088 
Kaufman, B.E. (2012). Strategic human resource management research in the United States: A failing grade after 30 years?. The Academy of Management Perspectives, 26(2), 12-36. https://doi.org/10.5465/amp.2012.0037

Knies, E., \& Leisink, P. (2014). Linking people management and extra-role behaviour: Results of a longitudinal study. Human Resource Management Journal, 24(1), 57-76. https://doi.org/10.1111/1748-8583.12023

Lawler III, E.E. (1986). High-Involvement Management. Participative Strategies for Improving Organizational Performance. San Francisco: Jossey-Bass Inc., Publishers.

Luna-Arocas, R., \& Morley, M.J. (2015). Talent management, talent mindset competency and job performance: The mediating role of job satisfaction. European Journal of International Management, 9(1), 28-51. https://doi.org/10.1504/EJIM.2015.066670

Marin-Garcia, J.A. (2013). What do we know about the relationship between High Involvement Work Practices and Performance?. Working Papers on Operations Management, 4(2), 1-15. https://doi.org/10.4995/wpom.v4i2.1552

Marin-Garcia, J.A., \& Conci, G. (2013). Validación de un cuestionario para medir el grado de uso de las prácticas de alta implicación de los trabajadores. Intangible Capital, 9(3), 854-882. https://doi.org/10.3926/ic.417

Marin-Garcia, J.A., \& Martinez Tomas, J. (2016). Deconstructing AMO framework: A systematic review. Intangible Capital, 12(4), 1040-1087. https://doi.org/10.3926/ic.838

Nishii, L.H., Lepak, D.P., \& Schneider, B. (2008). Employee attributions of the "why" of HR practices: Their effects on employee attitudes and behaviors, and customer satisfaction. Personnel Psychology, 61(3), 503-545. https://doi.org/10.1111/j.1744-6570.2008.00121.x

Nishii, L.H., \& Wright, P.M. (2007). Variability within organizations: Implications for strategic human resource management. CAHRS Working Paper Series, 7-2, 35. Retrieved from: http://digitalcommons.ilr.cornell.edu/cahrswp/467

Paul, A.K., \& Anantharaman, R.N. (2003). Impact of people management practices on organizational performance: Analysis of a causal model. International Journal of Human Resource Management, 14(7), 1246-1266. https://doi.org/10.1080/0958519032000145648

Perello-Marin, M.R., \& Ribes-Giner, G. (2014). Identifying a guiding list of high involvement practices in human resource management. WPOM-Working Papers on Operations Management, 5(1), 31-47.

https://doi.org/10.4995/wpom.v5i1.1495

PWC (2013). 16th Annual Global CEO Survey. The talent challenge A time for extraordinary leadership. Retrieved from: https://www.pwc.com/gx/en/hr-management-services/assets/ceosurvey-talentchallenge-2013.pdf (Last access date: September 21st, 2017)

PWC (2014). 17th Annual Global CEO Survey. Fit for the future Capitalising on global trends. Retrieved from; https://www.pwc.com/gx/en/ceo-survey/2014/assets/pwc-17th-annual-global-ceo-survey-jan-2014.pdf (Last access date: September 21st, 2017)

PWC (2015). 18th Annual Global CEO Survey. A marketplace without boundaries?. Responding to disruption. Retrieved from: https://www.pwc.com/gx/en/ceo-survey/2015/assets/pwc-18th-annual-global-ceo-survey-jan-2015.pdf (Last access date: September 21st, 2017)

PWC, \& WFPMA (2005). Survey of Global HR Challenges: Yesterday, today and tomorrow. Retrieved from: http://www.wfpma.com/hr-global-challenges (Last access date: September 21st, 2017)

Rynes, S.L., Colbert, A.E., \& Brown, K.G. (2002). HR Professionals' beliefs about effective human resource practices: Correspondence between research and practice. Human Resource Management, 41(2), 149-174. https://doi.org/10.1002/hrm.10029

SHRM (2010). SHRM Poll: Challenges Facing Organizations and HR in the Next 10 Years. Retrieved from: http://www.shrm.org/research/surveyfindings/articles/pages/challengesinnext10yrs.aspx (Last access date: September 21st, 2017) 
SHRM (2013a). 2012 Employee Job Satisfaction and Engagement. How Employees Are Dealing With Uncertainty. Retrieved from: http://www.shrm.org/Research/SurveyFindings/Articles/Documents/SHRM-Employee-Job-SatisfactionEngagement.pdf (Last access date: September 21st, 2017)

SHRM (2013b). SHRM Survey Findings: Employee Recognition Programs. Spring 2013. Retrieved from: http://www.shrm.org/research/surveyfindings/articles/pages/globoforce-employee-recognition-program.aspx (Last access date: September 21st, 2017)

SHRM (2013c). SHRM workplace forecast. The Top Workplace Trends According to HR Professionals. Retrieved from: https://www.shrm.org/ResourcesAndTools/hr-topics/behavioral-competencies/Documents/130146\%20workplace forecast full fnl.pdf (Last access date: September 21st, 2017)

SHRM (2014). Employee Job Satisfaction and Engagement. The Road to Economic Recovery. Retrieved from: https://www.shrm.org/hr-today/trends-and-forecasting/research-and-surveys/documents/140028\%20jobsatengage report full fnl.pdf (Last access date: September 21st, 2017)

SHRM (2015). SHRM Survey Findings: Employee Recognition Programs. 2015. Retrieved from: http://www.shrm.org/research/surveyfindings/articles/pages/shrm-globoforce-employee-recognition-2015.aspx (Last access date: September 21st, 2017)

Stone, D.L., \& Deadrick, D.L. (2015). Challenges and opportunities affecting the future of human resource management. Human Resource Management Review, 25(2), 139-145. https://doi.org/10.1016/j.hrmr.2015.01.003

Subramony, M. (2009). A meta-analytic investigation of the relationship between HRM bundles and firm performance. Human Resource Management, 48(5), 745-768. https://doi.org/10.1002/hrm.20315

Thunnissen, M., Boselie, P., \& Fruytier, B. (2013). A review of talent management:"infancy or adolescence"?. The International Journal of Human Resource Management, 24(9), 1744-1761. https://doi.org/10.1080/09585192.2013.777543

Ulrich, D., \& Dulebohn, J.H. (2015). Are we there yet? What's next for HR?. Human Resource Management Review, 25(2), 188-204. https://doi.org/10.1016/j.hrmr.2015.01.004

WEF, \& BCG (2011, January 1). Global Talent Risk - Seven Responses. Retrieved from: http://www3.weforum.org/docs/PS WEF GlobalTalentRisk Report 2011.pdf (Last access date: September 21st, 2017)

Wright, P.M., \& Boswell, W.R. (2002). Desegregating HRM: A Review and Synthesis of Micro and Macro Human Resource Management Research. Journal of Management, 28(3), 247-276.

https://doi.org/10.1177/014920630202800302 


\section{Annex A-1. Descriptive data for the reports under review}

\begin{tabular}{|c|c|c|c|c|c|c|c|c|c|c|}
\hline & & & & & & & & & & 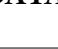 \\
\hline 苟 & ஜ̊ & 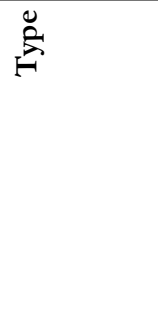 & 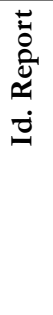 & 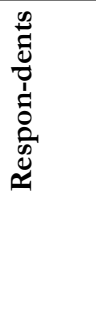 & 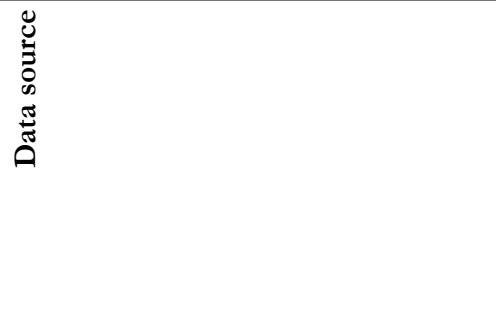 & 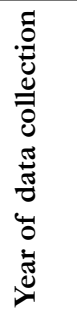 & 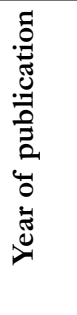 & 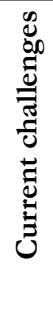 & 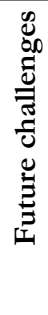 & $\stackrel{\infty}{8}$ \\
\hline GL & Global & ONE-OFF & 1. & 200 & Surveys & 2004 & 2005 & yes & yes & no \\
\hline GL & EEUU & SERIES & 2. & 449 & Surveys & 2010 & 2010 & no & yes & yes \\
\hline GL & Global & SERIES & 4. & 143 & Surveys & 2012 & 2013 & no & no & no \\
\hline GL & EEUU & SERIES & 4. & 216 & Survey with closed and open questions & 2011 & 2011 & yes & no & no \\
\hline GL & Europe & ONE-OFF & 9. & 1.355 & $\begin{array}{l}\text { Survey and in-depth interviews con } 100 \\
\text { CHRO's }\end{array}$ & 2009 & 2010 & no & yes & no \\
\hline GL & Global & SERIES & 10. & 4.288 & $\begin{array}{l}\text { Survey and in-depth interviews con } 63 \\
\text { executives }\end{array}$ & 2011 & 2012 & no & yes & yes \\
\hline GL & Global & SERIES & 11. & 1.304 & Surveys & 2012 & 2013 & no & yes & yes \\
\hline GL & Global & SERIES & 12. & 2.039 & Survey and in-depth interviews & 2010 & 2011 & yes & yes & yes \\
\hline GL & Global & SERIES & 13. & 5.561 & Survey and in-depth interviews & 2009 & 2010 & yes & yes & yes \\
\hline GL & EEUU & SERIES & 15. & 600 & Surveys & 2012 & 2013 & no & no & yes \\
\hline GL & EEUU & SERIES & 17. & 1.485 & Surveys & 2010 & 2013 & no & yes & yes \\
\hline GL & EEUU & SERIES & 19. & 75 & Survey with closed and open questions & 2010 & 2010 & yes & no & no \\
\hline GL & Global & SERIES & 20. & 600 & Surveys & 2013 & 2014 & no & no & yes \\
\hline GL & Global & SERIES & 21. & 803 & Surveys & 2013 & 2013 & yes & yes & yes \\
\hline GL & Spain & ONE-OFF & 22. & 294 & Surveys and in-depth interviews & 2014 & 2014 & no & yes & yes \\
\hline GL & Global & SERIES & 23. & 2.532 & Surveys & 2013 & 2014 & yes & no & no \\
\hline GL & Spain & ONE-OFF & 24. & 222 & Surveys & 2013 & 2014 & yes & no & yes \\
\hline GL & Global & SERIES & 25. & 3.500 & Surveys and in-depth interviews & 2014 & 2015 & no & yes & yes \\
\hline GL & Spain & SERIES & 26. & 4.700 & Surveys and in-depth interviews & 2008 & 2008 & no & yes & yes \\
\hline GL & Global & ONE-OFF & 29. & ND & $\begin{array}{l}\text { Working sessions of expert groups and } \\
\text { analysis of macroeconomic indicators }\end{array}$ & 2011 & 2011 & no & no & yes \\
\hline GL & Global & SERIES & 30. & 1.300 & Surveys & 2012 & 2013 & yes & yes & no \\
\hline GL & Global & SERIES & 31. & 3.300 & Surveys & 2014 & 2015 & yes & no & no \\
\hline GL & Spain & SERIES & 32. & 219 & Surveys & 2014 & 2015 & yes & no & yes \\
\hline \multirow[t]{2}{*}{ GL } & US & SERIES & 33. & 832 & Surveys & 2015 & 2015 & yes & no & yes \\
\hline & & & & & & & & 12 & 13 & 16 \\
\hline
\end{tabular}

\section{Annex A-2. Descriptive identification for the reports under review}

\begin{tabular}{|c|c|}
\hline Id. Report title & Editor \\
\hline 1.Survey of Global HR Challenges: Yesterday, today and tomorrow (PWC \& WFPMA, 2005) & WFPMA -PWC \\
\hline 2.Challenges Facing HR Over the next 10 years (SHRM, 2010) & SHRM \\
\hline 4..HR in the C-Suite: CAHRS 2012 Chief Human Resource Officer Survey Results (CAHRS, 2013) & $\begin{array}{l}\text { (CAHRS). Cornell } \\
\text { University }\end{array}$ \\
\hline $\begin{array}{l}\text { 5. The } 2011 \text { CHRO Challenge: Building organizational, functional and personal talent. HR in the C- } \\
\text { Suite: CAHRS } 2011 \text { Chief Human Resource Officer Survey Results (CAHRS, 2011) }\end{array}$ & $\begin{array}{l}\text { Center for Advanced } \\
\text { Human Resource Studies } \\
\text { (CAHRS). Cornell } \\
\text { University }\end{array}$ \\
\hline 9. The future of HR in Europe. Key Challenges through 2015 (BCG \& EAPM, 2010) & $\begin{array}{l}\text { EAPM (European } \\
\text { Association for personnel } \\
\text { management) }\end{array}$ \\
\hline $\begin{array}{l}\text { 10.Creating people advantage 2012. Mastering HR challenges in a two speed world (BCG \& WFPMA, } \\
\text { 2012) }\end{array}$ & BCG-WFPMA \\
\hline 11.Creating people advantage 2013. Lifting HR practices to the next level (BCG \& EAPM, 2013) & BCG-WFPMA \\
\hline $\begin{array}{l}\text { 12. Creating people advantage 2011. Time to Act: HR certainties in uncertain times (BCG \& EAPM, } \\
\text { 2011) }\end{array}$ & BCG-WFPMA \\
\hline $\begin{array}{l}\text { 13.Creating people advantage 2010. How companies can adapt their practices for volatile times (BCG } \\
\text { \& WFPMA, 2010) }\end{array}$ & BCG-WFPMA \\
\hline 15.2012 Employee job satisfaction and engagement. How employees are dealing... (SHRM, 2013a) & SHRM \\
\hline
\end{tabular}




\begin{tabular}{|l|l|}
\hline $\begin{array}{l}\text { 17.SHRM workplace forecast. The top workplace trends according to HR professionals (SHRM, } \\
\text { 2013c) }\end{array}$ & SHRM \\
\hline $\begin{array}{l}\text { 19.(CAHRS) From bunker to building: results from the 2010 chief human resource officer (CAHRS, } \\
\text { 2010) }\end{array}$ & $\begin{array}{l}\text { Center for Advanced } \\
\text { Human Resource Studies } \\
\text { (CAHRS). Cornell } \\
\text { University }\end{array}$ \\
\hline $\begin{array}{l}\text { 20. Employee Job Satisfaction and Engagement. The Road to Economic Recovery (SHRM, 2014) } \\
\text { 21.SHRM survey findings: employee recognition programs, spring 2013 (SHRM, 2013b) }\end{array}$ & SHRM \\
\hline $\begin{array}{l}\text { 22.Odisea 2017. Gestionando personas en tiempos de cambio (APD \& People-excellence-consulting, } \\
\text { 2014) }\end{array}$ & SHRM+GLOBOFORCE \\
\hline 23.Global human capital trends 2014. Engaging the 21st-century workforce (Deloitte, 2014) & \\
\hline 24.Estudio de Prioridades y Tendencias: Recursos Humanos 2014 (Garrigues, 2014) \\
\hline $\begin{array}{l}\text { 25.Creating people advantage 2014-2015. how to set up great HR functions: connect, prioritize, impact } \\
\text { (BCG \& WFPMA, 2015) }\end{array}$ & BCG-WFPMA \\
\hline 26.Como afrontar los desafios de rrhh en todo el mundo hasta el 2015 (BCG, 2008) \\
\hline 29. World economic forum. Global talent risk. Seven responses (WEF \& BCG, 2011) & BCG \\
\hline 30. Global Human Capital Trends 2013. Resetting Horizons (Deloitte, 2013) & World economic forum \\
\hline 31. Global Human Capital Trends 2015. Leading in the new world of work (Deloitte, 2015) & Deloitte \\
\hline 32. Estudio de prioridades y tendencias. Recursos humanos 2015 (Garrigues, 2015) & Deloitte \\
\hline 33.SHRM survey findings: employee recognition programs, spring 2015 (SHRM, 2015) & Garrigues \\
\hline
\end{tabular}

\section{Annex B. Challenges identified for the period under review}

\begin{tabular}{|c|c|c|c|c|c|c|c|c|c|c|c|c|c|}
\hline & Id. Report (see title in annex A) & 1. & 13. & 19. & 12. & 5. & 30. & 24. & 23. & 21. & 31. & 32. & 33. \\
\hline & Year of data & 2004 & 2009 & 2010 & 2010 & 2011 & 2012 & 2013 & 2013 & 2013 & 2014 & 2014 & 2015 \\
\hline \multicolumn{2}{|c|}{ Code challenge/ Year of Publication } & 2005 & 2010 & 2010 & 2011 & 2011 & 2013 & 2014 & 2014 & 2013 & 2015 & 2015 & 2015 \\
\hline 1 & Talent management & & 1 & 1 & 1 & 1 & 1 & 1 & 1 & & 1 & 1 & 1 \\
\hline 2 & $\begin{array}{l}\text { Improving leadership } \\
\text { development }\end{array}$ & 1 & 1 & 1 & 1 & 1 & 1 & & 1 & & 1 & & \\
\hline 3 & Employee engagement & & 1 & & & 1 & 1 & & 1 & 1 & 1 & & \\
\hline 4 & Retaining the best employees & & 1 & 1 & 1 & & & & 1 & 1 & & & 1 \\
\hline 5 & $\begin{array}{l}\text { Total Rewards/Compensation } \\
\text { and Benefits }\end{array}$ & 1 & & 1 & & 1 & & 1 & & & & 1 & \\
\hline 6 & $\begin{array}{l}\text { Management of corporate } \\
\text { culture }\end{array}$ & & & & & 1 & & 1 & & 1 & & & \\
\hline 7 & Executive succession planning & & & 1 & & & & & & 1 & & & 1 \\
\hline 8 & $\begin{array}{l}\text { Training - Learning and people } \\
\text { development }\end{array}$ & & & & & & & 1 & 1 & 1 & & 1 & \\
\hline 9 & Organizational effectiveness & 1 & & & & & & & & & & 1 & 1 \\
\hline 10 & $\begin{array}{l}\text { Measuring workforce } \\
\text { performance }\end{array}$ & 1 & 1 & & & & & & & & 1 & & 1 \\
\hline 11 & $\begin{array}{l}\text { Innovation. Selection and use } \\
\text { of HR technology/HR } \\
\text { analytics }\end{array}$ & & & & & & & & 1 & & 1 & 1 & \\
\hline 12 & Improving employer branding & & & & & & 1 & 1 & & & & & \\
\hline 13 & Change management & 1 & & & & & 1 & & & & & & \\
\hline 14 & $\begin{array}{l}\text { Transforming HR into a } \\
\text { strategic partner }\end{array}$ & & & & & & 1 & & & & 1 & & \\
\hline 15 & Recruitment and selection & 1 & & & 1 & & & & & & & & \\
\hline 16 & Managing work-life balance & & & & 1 & & & & & & & & \\
\hline 17 & Legal and administrative issues & & 1 & & & & & & & & & & \\
\hline 18 & Labor relationship & & & & & & & & & & & 1 & \\
\hline 19 & Employee mobility & & & & & & & & & & & & \\
\hline 20 & Strategic workforce planning & & & & & & & & & & & & \\
\hline
\end{tabular}


Annex C. Future challenges for each period under review

\begin{tabular}{|c|c|c|c|c|c|c|c|c|c|c|c|c|c|c|c|c|}
\hline & Id. Report & 1. & 26. & 13. & 9. & 2. & 17. & 12. & 10. & 11. & 2. & 30. & 17. & 25. & 21. & 22. \\
\hline & Data from & 2004 & 2008 & 2009 & 2009 & 2010 & 2010 & 2010 & 2011 & 2012 & 2012 & 2012 & 2012 & 2013 & 2013 & 2014 \\
\hline \multicolumn{2}{|c|}{ Code Challenge /Year of publlication } & 2005 & 2008 & 2010 & 2010 & 2010 & 2013 & 2011 & 2012 & 2013 & 2012 & 2013 & 2013 & 2014 & 2013 & 2014 \\
\hline 1 & Talent management & & 1 & 1 & 1 & 1 & 1 & 1 & 1 & 1 & 1 & 1 & 1 & 1 & 1 & 1 \\
\hline 2 & $\begin{array}{l}\text { Improving leadership } \\
\text { development }\end{array}$ & & 1 & 1 & 1 & 1 & 1 & 1 & 1 & 1 & 1 & & 1 & 1 & 1 & \\
\hline 3 & Employee engagement & & 1 & 1 & & & & 1 & 1 & 1 & & & & 1 & & \\
\hline 4 & Retaining the best employees & 1 & & & & 1 & 1 & & & & 1 & & 1 & & 1 & 1 \\
\hline 5 & $\begin{array}{l}\text { Total Rewards/Compensation } \\
\text { and Benefits }\end{array}$ & & & & & & & & & & & & & & & \\
\hline 6 & $\begin{array}{l}\text { Management of corporate } \\
\text { culture }\end{array}$ & & & & & & & & 1 & 1 & & & & 1 & & \\
\hline 7 & Executive succession planning & & & & & & & & & & & 1 & & & 1 & \\
\hline 8 & $\begin{array}{l}\text { Training - Learning and people } \\
\text { development }\end{array}$ & & 1 & & & & & & & 1 & & & & & 1 & \\
\hline 9 & Organizational effectiveness & 1 & & & 1 & & & & & & & & & & & \\
\hline 10 & $\begin{array}{l}\text { Measuring workforce } \\
\text { performance }\end{array}$ & & & 1 & & & & 1 & & 1 & & 1 & 1 & & & \\
\hline 11 & $\begin{array}{l}\text { Innovation. Selection and use } \\
\text { of HR technology/HR } \\
\text { analytics }\end{array}$ & & & & & & & & & 1 & & & & 1 & & \\
\hline 12 & Improving employer branding & & & & & 1 & 1 & & & & 1 & 1 & 1 & & & \\
\hline 13 & Change management & 1 & & 1 & 1 & & & 1 & & & & & & & & 1 \\
\hline 14 & $\begin{array}{l}\text { Transforming HR into a } \\
\text { strategic partner }\end{array}$ & & 1 & 1 & 1 & & & 1 & 1 & & & & & & & 1 \\
\hline 15 & Recruitment and selection & 1 & & & 1 & 1 & 1 & & & & 1 & 1 & 1 & & 1 & \\
\hline 16 & Managing work-life balance & & 1 & & 1 & & & & & & & & & & & \\
\hline 17 & Legal and administrative issues & & 1 & & & & & & & & & & & & & \\
\hline 18 & Labour relationship & & & & & & & & & & & & & & & \\
\hline 19 & Employee mobility & 1 & & & & & & & & & & & & & & \\
\hline 20 & Strategic workforce planning & & & 1 & & & & 1 & 1 & & & & & 1 & & \\
\hline
\end{tabular}

Intangible Capital, 2019 (www.intangiblecapital.org)

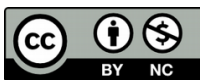

Article's contents are provided on an Attribution-Non Commercial 4.0 Creative commons International License. Readers are allowed to copy, distribute and communicate article's contents, provided the author's and Intangible Capital's names are included. It must not be used for commercial purposes. To see the complete license contents, please visit https://creativecommons.org/licenses/by-nc/4.0/. 